\title{
Melanoma: the role of surgery in the era of new therapies
}

\author{
Nicola Mozzillo and Paolo A Ascierto*
}

Stage IV melanoma has historically been associated with poor outcomes, with a typical one-year survival rate of around 25\% [1]. In particular, patients who develop distant metastases have a poor prognosis. Treatment of these patients involves systemic medical therapy, radiotherapy and surgery.

However, systemic drug therapy as a treatment option has generally been ineffective in metastatic melanoma. Although several single-agent chemotherapies have shown activity against melanoma, complete responses are rare, with overall response rates of $8-23 \%$ and median overall survival (OS) of 6-11 months [2]. A meta-analysis of 48 studies demonstrated that the benefit from any of the various combinations of chemotherapy and biochemotherapy is about $4.2 \%$, with a mean OS of 6 months [3].

However, recent years have seen an improvement in our understanding of the melanoma metastatic cascade, providing important new information about the molecular events that drive melanoma initiation and progression and allowing the development of novel therapies. In 2011, ipilimumab was the first new agent approved for the treatment of patients with advanced melanoma in over three decades. Ipilimumab is a fully human monoclonal antibody directed against cytotoxic T-lymphocyteassociated antigen-4 (CTLA-4), a negative regulator of T-cell-mediated immune responses. In phase III trials, treatment with ipilimumab significantly extended OS compared with control in both pre-treated and treatmentnaïve patients, and follow-up data from clinical trials suggest ipilimumab can provide durable clinical benefit and long-term survival $[4,5]$. The patterns of tumour response to ipilimumab differ from those observed with cytotoxic chemotherapies, since patients may have a delayed yet durable response and obtain long-term survival benefit despite initial tumour growth. Approximately $10 \%$ of patients have objective responses by standard criteria, whereas $10-20 \%$ show stable disease or minor responses that

\footnotetext{
* Correspondence: paolo.ascierto@gmail.com

Department of Melanoma and Soft Tissue, Istituto Nazionale Tumori Fondazione "G. Pascale", Via Mariano Semmola, 80131 Naples, Italy
}

translate into a clinical benefit [6,7]. In most patients, the onset of clinical response is between weeks 12 and 24 and may persist for $\geq 1$ year before maximal response occurs.

The first targeted therapy for advanced melanoma with a favorable impact on survival, vemurafenib, was also approved in 2011. Vemurafenib is a tyrosine kinase inhibitor of the oncogenic BRAFV600 protein kinase. Approximately 50\% of melanomas harbour activating BRAF mutations, especially those patients with tumours arising on skin without chronic sun-induced damage [8]. In clinical trials, treatment with vemurafenib was associated with an OS of $77 \%$ at 6 months and 58\% at 12 months, although median OS remained at 13.6 months due to disease relapses $[9,10]$. Other targeted therapies are also in development, either with the same molecular target (e.g. dabrafenib), or targeting steps in the pathway downstream of BRAF (e.g. MEK inhibitors). Further improvements in targeted approaches are expected from ongoing clinical trials, aiming to potentiate the activity of BRAF inhibitors through combined or sequential therapy with other molecules, both immune-based and other targeted agents [11]. These combination therapies (e.g. BRAF plus MEK inhibitors) also aim at lowering the skin toxicities observed with BRAF inhibition.

Despite the major advances offered by these new systemic therapies, surgery of stage IV melanoma remains an important therapeutic tool that can be used to rapidly and safely resolve localised disease. The rational for surgical resection as first option in stage IV melanoma is based on several factors. Single lesions are best treated by surgery while studies have shown complete resection is possible in $25 \%$ of stage IV patients (M1a through M1c inclusive) [12]. The surgical procedure has acceptable morbidity and mortality and is associated with favourable survival rates [13].

Several prognostic factors for surgery in metastatic melanoma have been identified (Table 1). In particular, patients who have limited sites of metastatic disease, prolonged disease-free survival and a tumour-volume doubling time of $>60$ days may be amenable to surgical 
Table 1 Prognostic factors for surgical resection in stage IV melanoma

\begin{tabular}{ll}
\hline Major & Ability to achieve complete surgical resection \\
& Initial site of metastasis \\
& Number of metastatic lesions \\
Tumour-volume doubling time & Disease-free interval \\
Minor & Preceding stage
\end{tabular}

resection [14-16]. It is also important to consider whether the disease burden can be completely resected. Complete surgical excision of limited metastatic disease can result in prolonged progression-free survival (PFS) in carefully selected patients. Surgery for distant metastatic melanoma, however, is rarely curative since the majority of patients with distant metastases have widespread micrometastatic disease even if clinical and imaging criteria suggest limited spread.

The rationale for considering surgery as a major component of metastatic melanoma therapy is further supported by the observation that repeat resection of recurrent distant metastatic melanoma can prolong survival and that metastases can themselves metastasize. The potential for surgery to benefit individual patients is suggested by the results of a prospective, phase II study from the Southwest Oncology Group, in which 64 of 77 carefully selected patients underwent complete resection of all sites of metastatic disease [17]. At a median follow-up of five years, the median durations of PFS and OS were 5 and 21 months, respectively. Overall, the three- and four-year survival rates were $36 \%$ and $31 \%$, although late relapses continued to be observed after this time. Resection should be reserved for the relief or prevention of morbidity due to local tumor growth and for patients in whom a longer survival might be expected with surgical rather than medical treatment.

Large tumour masses are difficult to eradicate with systemic therapy alone and surgery in combination with novel immuno- and targeted therapies can potentially improve clinical outcomes and/or patients' quality of life. Indeed, surgery should be offered to reduce the target of subsequent adjuvant medical treatment whenever possible.

BRAF inhibitors (vemurafenib and dabrafenib) alone and in combination (dabrafenib/trametinib, vemurafenib/ cobimetinib, encorafenib/binimetinib) can have a significant clinical impact with a rapid improvement in symptoms and metabolic shut-down at PET scan assessment. However, not all metastatic sites respond to therapy and surgery may be required to remove resistant lesions. Data from a phase I study [18] and from an expanded access program [19] clearly indicate improved PFS and OS in patients with a low tumoural volume, suggesting that the use of surgery to remove resistant clones and reduce tumour burden may be beneficial. Indeed, data from a phase I trial evidenced that, for a subset of patients with disease progression, continuation of vemurafenib treatment is potentially beneficial after local therapy [20]. In this study, 18 patients who continued vemurafenib $>30$ days after surgery or radiotherapy at a site of disease progression had a median overall survival of over 15.5 months from initiation of BRAF inhibitor therapy. This compares with a median overall survival of 1.4 months in patients who did not continue treatment. Moreover, patients with low tumour burden seemed to have a better response to vemurafenib.

Surgery may also have an important role in combination with immunotherapy. Indeed, the removal of lesions that may be resistant to treatment with ipilimumab may improve outcomes for some patients. Pathological evaluation of the excised tissue is important to assess the presence of immune-infiltrate. In several cases, analysis of the excised tissue has revealed the presence of a diffuse immune infiltration which correlated with the outcome of these patients [21]. Thus, reduction of the tumor mass which can be obtained with surgery is important in combination with immunotherapy.

In conclusion, surgery still represents one of the four pillars of treatment for stage IV melanoma, together with radiotherapy, chemotherapy and new immunotherapy approaches.

\section{Competing interests}

PAA received research funding from Bristol-Myers Squibb, Roche-Genentech, and Ventana. He also has/had a consultant or advisory role for Bristol-Myers Squibb, Roche-Genentech, Merck Sharp \& Dohme, GlaxoSmithKline, Ventana, and Novartis. He received honoraria from Bristol-Myers Squibb, Roche-Genentech, and GlaxoSmithKline. NM has no competing interest to declare.

Authors' contribution

NM and PAA drafted and approved the final manuscript.

Received: 3 July 2014 Accepted: 5 July 2014

Published: 11 July 2014

\section{References}

1. Korn EL, Liu PY, Lee SJ, Chapman JA, Niedzwiecki D, Suman VJ, Moon J, Sondak VK, Atkins MB, Eisenhauer EA, Parulekar W, Markovic SN, Saxman S, Kirkwood JM: Meta-analysis of phase II cooperative group trials in metastatic stage IV melanoma to determine progression-free and overall survival benchmarks for future phase II trials. J Clin Oncol 2008, 26:527-534.

2. Reeves $E$, Bridge $P$, Appleyard RM: The current role of systemic therapy in the management of malignant melanoma of the skin: a literature review. J Radiother Pract 2005, 4:161-175.

3. Lui P, Cashin R, Machado M, Hemels M, Corey-Lisle PK, Einarson TR: Treatments for metastatic melanoma: synthesis of evidence from randomized trials. Cancer Treat Rev 2007, 33:665-680.

4. Hodi FS, O'Day SJ, MCDermott DF, Weber RW, Sosman JA, Haanen JB, Gonzalez R, Robert C, Schadendorf D, Hassel JC, Akerley W, van den Eertwegh AJ, Lutzky J, Lorigan P, Vaubel JM, Linette GP, Hogg D, Ottensmeier CH, Lebbé C, Peschel C, Quirt I, Clark Jl, Wolchok JD, Weber JS, Tian J, Yellin MJ, Nichol GM, Hoos A, Urba WJ: Improved survival with ipilimumab in patients with metastatic melanoma. N Engl J Med 2010, 363:711-723.

5. Robert C, Thomas L, Bondarenko I, O'Day S, JW MD, Garbe C, Lebbe C, Baurain JF, Testori A, Grob JJ, Davidson N, Richards J, Maio M, Hauschild A, 
Miller WH Jr, Gascon P, Lotem M, Harmankaya K, Ibrahim R, Francis S, Chen TT, Humphrey R, Hoos A, Wolchok JD: Ipilimumab plus dacarbazine for previously untreated metastatic melanoma. N Engl J Med 2011 364:2517-2526.

6. Ascierto PA, Marincola FM, Ribas A: Anti-CTLA4 monoclonal antibodies: the past and the future in clinical application. J Transl Med 2011, 9:196

7. Ascierto PA, Marincola FM: What have we learned from cancer immunotherapy in the last 3 years? J Transl Med 2014, 12:141.

8. Ascierto PA, Kirkwood JM, Grob JJ, Simeone E, Grimaldi AM, Maio M, Palmieri G, Testori A, Marincola FM, Mozzillo N: The role of BRAF V600 mutation in melanoma. J Transl Med 2012, 10:85.

9. Chapman PB, Hauschild A, Robert C, Haanen JB, Ascierto P, Larkin J, Dummer R, Garbe C, Testori A, Maio M, Hogg D, Lorigan P, Lebbe C, Jouary T, Schadendorf D, Ribas A, O'Day SJ, Sosman JA, Kirkwood JM, Eggermont AM, Dreno B, Nolop K, Li J, Nelson B, Hou J, Lee RJ, Flaherty KT, McArthur GA, BRIM-3 Study Group: Improved survival with vemurafenib in melanoma with BRAF V600E mutation. N Engl I Med 2011, 364:2507-2516.

10. McArthur GA, Chapman PB, Robert C, Larkin J, Haanen JB, Dummer R, Ribas A, Hogg D, Hamid O, Ascierto PA, Garbe C, Testori A, Maio M, Lorigan P, Lebbé C, Jouary T, Schadendorf D, O'Day SJ, Kirkwood JM, Eggermont AM, Dréno B, Sosman JA, Flaherty KT, Yin M, Caro I, Cheng S, Trunzer K, Hauschild A: Safety and efficacy of vemurafenib in BRAF(V600E) and BRAF(V600K) mutation-positive melanoma (BRIM-3): extended follow-up of a phase 3, randomised, open-label study. Lancet Oncol 2014, 15:323-332.

11. Ascierto PA, Streicher HZ, Sznol M: Melanoma: a model for testing new agents in combination therapies. J Transl Med 2010, 8:38.

12. Hoshimoto S, Faries MB, Morton DL, Shingai T, KUO C, Wang HJ, Elashoff R, Mozzillo N, Kelley MC, Thompson JF, Lee JE, Hoon DS: Assessment of prognostic circulating tumor cells in a phase III Trial of adjuvant immunotherapy after complete resection of stage IV melanoma. Ann Surg 2012, 255:357-362

13. Howard JH, Thompson JF, Mozzillo N, Nieweg OE, Hoekstra MJ, Roses DF, Sondar VK, Reintgen DS, Rasmai-Sabet M, Karavousis CP, Coventry BJ, Kraybill WG, Smithers BM, Elashoff R, Stern SL, Cohran AJ, Faries MB, Morton DL: Metastasectomy for distant metastatic melanoma: analysis of data from the first MSLT (MSLT I). Ann Surg Oncol 2012, 19:2547-2555.

14. Meyer T, Merkel S, Goehl J, Hohenberger W: Surgical therapy for distant metastases of malignant melanoma. Cancer 2000, 89:1983-1991.

15. Tafra L, Dale PS, Wanek LA, Ramming KP, Morton DL: Resection and adjuvant immunotherapy for melanoma metastatic to the lung and thorax. J Thorac Cardiovasc Surg 1995, 110:119-128.

16. Ollila DW, Stern SL, Morton DL: Tumor doubling time: a selection factor for pulmonary resection of metastatic melanoma. J Surg Oncol 1998 69:206-211.

17. Sosman JA, Moon J, Tuthill RJ, Warneke JA, Vetto JT, Redman BG, Liu PY, Unger JM, Flaherty LE, Sondak VK: A phase 2 trial of complete resection for stage IV melanoma: results of Southwest Oncology Group Clinical Trial S9430. Cancer 2011, 117:4740-06.

18. Amaravadi RK, Kim KB, Flaherty KT, Chapman P, Puzanov I, Sosman J, Ribas A, Lee R, Nolop K, McArthur GA: Prolonged responses to vemurafenib in patients with BRAF V600E mutant melanoma with low tumor burden at baseline. Pigment Cell Res 2011, 24(3):1024.

19. Larkin J, Del Vecchio M, Ascierto PA, Krajsova I, Schachter J, Neyns B, Espinosa E, Garbe C, Sileni VC, Gogas H, Miller WH Jr, Mandalà M, Hospers GA, Arance A, Queirolo P, Hauschild A, Brown MP, Mitchell L, Veronese L, Blank CU: Vemurafenib in patients with BRAF(V600) mutated metastatic melanoma: an open-label, multicentre, safety study. Lancet Oncol 2014, 15:436-444

20. Kim KB, Flaherty KT, Chapman PB, Sosman JA, Ribas A, McArthur GA Amaravadi RK, Lee RJ, Nolop KB, Puzanov I: Pattern and outcome of disease progression in phase I study of vemurafenib in patients with metastatic melanoma (MM). J Clin Oncol 2011, 29(8519):530s.
21. Simeone E, Gentilcore G, Giannarelli D, Grimaldi AM, Caracò C, Curvietto M, Esposito A, Paone M, Palla M, Cavalcanti E, Sandomenico F, Petrillo A, Botti G, Fulciniti F, Palmieri G, Queirolo P, Marchetti P, Ferraresi V, Rinaldi G, Pistillo MP, Ciliberto G, Mozzillo N, Ascierto PA: Immunological and biological Changes during ipilimumab treatment and their potential correlation with clinical response and survival in patients with advanced melanoma. Cancer Immunol Immunother 2014, 63:675-683.

doi:10.1186/1479-5876-12-195

Cite this article as: Mozzillo and Ascierto: Melanoma: the role of surgery in the era of new therapies. Journal of Translational Medicine 2014 12:195.

\section{Submit your next manuscript to BioMed Central and take full advantage of:}

- Convenient online submission

- Thorough peer review

- No space constraints or color figure charges

- Immediate publication on acceptance

- Inclusion in PubMed, CAS, Scopus and Google Scholar

- Research which is freely available for redistribution

Submit your manuscript at www.biomedcentral.com/submit
( BioMed Central 